\title{
COMPARISON OF THE MOTOR DEVELOPMENT IN PRETERM INFANTS FROM TWO BRAZILIAN REGIONAL SAMPLES
}

\author{
Cibelle Kayenne Martins Roberto Formiga ${ }^{1}$, Jamilie Carvalho Rodrigues Nonato ${ }^{2}$, \\ Lívia Ellen França do Amaral ${ }^{3}$, Rayne Ramos Fagundes ${ }^{4}$, Maria Beatriz Martins Linhares ${ }^{5}$
}

\begin{abstract}
Objective: The present study sought to compare the motor development of the preterm infants of two Brazilian regional samples, using a reliable scale evaluation to determine the influence that the environment can have on infants exposed to perinatal conditions and similar risk factors. Materials and Methods: Two cross-sectional samples of preterm low-birthweight infants were used: a study group (SG = 70) and a control group ( CG = 43). The assessment tool used was the Alberta Infant Motor Scale (AIMS). Results: There were no statistically significant differences in total score on the AIMS, although some differences were noted in the gestational age variable (at 2, 3 and 4 months of age) and the birth weight variable (weight slightly above that of the CG) among infants. There was also a difference in the classification of motor development at 2 and 3 months of age corrected in accordance with the standard scale, on which the SG was ranked as behindhand in relation to the CG. Conclusion: The results suggest that preterm infants from different regions show the same rate of progress in their motor development, even when subject to different environmental influences. It is, further, suggested that this study should be extended so as to permit a more detailed control of the environment (including the maternal practices) in which the infant is being brought up.
\end{abstract}

Key words: prematurity, child development, motor skills, risk factors, physiotherapy.

\section{INTRODUCTION}

The study of human development seeks to understand the changes that the body undergoes during its lifespan. Several analyses, especially those related to child development, have been undertaken to identify similarities and differences in the behavior of children during their early years ${ }^{1}$.

Child development is a continuous process that begins at conception with a view to enabling the child to meet its needs. It comprises the physical growth and the neurological, behavioral, cognitive, social and affective maturation of the child ${ }^{1}$.

Such development can be influenced by diverse factors ${ }^{2}$. Among them are the biological events that constitute the pre, peri and postnatal periods, one example being the gestational age and the genetic inheritance received by the child from its parents. There are also some environmental factors involved, including the mother's health and nutritional status, the quantity and quality of the family's social resources, maternal educational level and the stimuli and care the child receives during pregnancy and after birth ${ }^{1}$.

These factors can exercise positive or negative influence, and in this latter case, there may be an enhancement of risk factors which then become what are known as developmental problems ${ }^{2}$. Such problems have varied clinical presentations, and include language disorders, changes in personal-social interactions and cognitive skills, as well as in the child's motor development (gross or fine) $)^{1,3}$.

One of the main causes of perinatal morbidity and mortality is related to the gestational age (GA) of the fetus ${ }^{4}$. According to the GA, the newborn may be classified as: preterm (born at less than 37 weeks' gestation), full term (born between 37 and 42 weeks' gestation) and post-term (birth after 42 weeks' gestation $)^{5}$. Prematurity significantly influences the motor development of infants and may contribute to an onset of delays ${ }^{6}$.

\footnotetext{
1 Physical Therapist, Doctor of Medical Science at FMRP/USP, Head Professor at the State University of Goiás (UEG) - ESEFFEGO, Goiânia (GO).

2 Graduate degree in Physical Therapy at the State University of Goiás (UEG) - ESEFFEGO, Goiânia (GO).

3 Academician at the State University of Goiás (UEG) - ESEFFEGO, Goiânia (GO), PBIC/UEG scholar.

4 Academician at the State University of Goiás (UEG) - ESEFFEGO, Goiânia (GO), PIBIC/CNPQ scholar.

5 Psychologist, Full Professor at FMRP/USP. Address: Av. Bandeirantes, No 3900, Monte Alegre Ribeirão Preto (SP).

Physical Therapy Course at the State University of Goiás (UEG) - ESEFFEGO

Corresponding Author: liviahellen@hotmail.com / cibellekayenne@gmail.com
}

Suggested citation: Formiga CKMR, et al. Comparison of the motor development in preterm infants from two brazilian regional samples. Journal of Human Growth and Development 2013; 23(3): 352-357

Manuscript submitted Oct 15 2012, accepted for publication Mai 022013. 
Newborn preterm infants (PI) have a higher mortality rate and also have a higher risk of developing disorders and other sequelae that affect them both in the neonatal stage, as well as later in their development in general ${ }^{7}$, which is corroborated by various studies that correlate prematurity and delayed motor development $8,9,10,11$.

As regards birth weight, the term "very low birth weight" defines infants who weigh between 1000 and $1500 \mathrm{~g}$, and "extremely low birth weight" refers to newborn weighing less than $1000 \mathrm{~g}$. These two groups consist of vulnerable infants at risk of impaired growth and psychological development ${ }^{12}$.

The rate of premature births and low birth weight infants $(<2,500 \mathrm{~g})$ is higher in less developed countries such as Brazil ${ }^{13}$ and has become a global public health problem ${ }^{14}$.

In the last two decades several modern perinatal techniques have been introduced which has resulted in a reduction of the mortality of preterm infants, which has led, in its turn, to an increase of the risk of developmental delays, especially in the motor area during early life ${ }^{15,16}$.

The disturbances shown by a significant number of these infants are related to learning skills, language difficulties, behavioral problems, deficits in motor coordination and visual-spatial perception in school age ${ }^{17}$.

The motor assessment of preterm infants is of the utmost importance for the monitoring of their development. For this purpose, highly accurate standardized scales, capable of measuring the movements of the infant qualitatively at a determined and expected motor age, are used. Through such tools it is possible to monitor developmental disorders and, if necessary, refer the child for early intervention ${ }^{18}$.

Many assessment tools are currently being used. Among the formal tests reported in the study of motor development from birth to 18 months of age is the Alberta Infant Motor Scale (AIMS) ${ }^{19}$, a Canadian scale used to assess the gross motor development ${ }^{10}$ of pre- and full term infants. Its objective is to determine whether the NBPTI shows any delay in motor performance as compared to that of full term infants ${ }^{20}$ and evaluate the motor development of healthy or at risk infants from their birth until the acquisition of gait independence ${ }^{19}$.

This is a validated and reliable tool, which provides a high rate of intra- and interobserver reliability. It accompanies the gross motor development, and classifies infants on a development curve between the fifth and ninth percentile ${ }^{21}$. It is considered a cross-cultural scale and has been used in numerous research projects ${ }^{22}$.

The present study evaluated the motor development of preterm infants from birth to six months of corrected age from two different regions of Brazil by means of a reliable scale evaluation. The aim is to investigate the influence that the environmental context can have on infants exposed to perinatal conditions and similar risk factors.

\section{METHODS}

This research consisted of data analysis with the descriptive and comparative purposes which characterize a cross-sectional study. Two samples of preterm infants were used: a study group (SG) and a control group (CG). The SG sample included 70 preterm infants of both sexes, selected from among infants born at the High Risk Clinic of the Children's Hospital ( $\mathrm{CH}$ ) of Goiania (GO) during the period from 2004 to 2006, with a gestational age of less than 37 weeks, birth weight of less than $2500 \mathrm{~g}$ and corrected age of between zero and six months.

The exclusion criteria were: being a bearer of any genetic or malformation syndrome, being affected by musculoskeletal disorders, persistent sensory impairments, peri-intraventricular hemorrhage $(\mathrm{P} / \mathrm{IVH})$ grades III and IV, hypoxic ischemic encephalopathy (HIE) grades II and III, neurological abnormalities (postural and movement asymmetries, involuntary movements, hypotonia or hypertonia on neurological evaluation, cerebral palsy or seizures).

The CG sample was composed of 43 preterm infants from the Nursery of the Maternity Hospital of the Faculty of Medicine, University of São Paulo (HC-FMUSP). That sample was drawn from a study published by Restiffe ${ }^{23}$.

The SG study was approved by the Research Ethics Committee of the General Hospital of Goiânia under the protocol Cepha-HGG No. 73/2004, in accordance with the provisions and principles of Resolution 196/96 of the National Health Council. The children's parents or guardians authorized their participation in the study by signing an informed consent form on which the overall goals of the research, the voluntary nature of their participation and the importance of the research in the infants' development were described.

The infants of the SG were assessed in a room at the High Risk Clinic of the $\mathrm{CH}$, as per the AIMS. The chronological age was corrected at the time of the evaluation, so that no mistake would be made when detecting delays in the infants' development. Each infant had its score registered in its personal health records and the data were stored on videorecordings.

A total score, i.e., the sum of the items noted in the four scale positions: prone, supine, sitting and standing, was attributed after the analysis of the video recordings. The sample data were analyzed at the Center for Interdisciplinary Research at ESEFFEGO (NIPE).

The total score obtained on the AIMS was used at the time of conclusion of the results to ensure greater reliability when comparing the motor performance of each infant. The scores were then graded, according to the following categories, by using a development curve, as: a) normal, if the corresponding percentile was $>50$; b) suspicious or borderline, if the percentile was $>10$ and $<50$, or c) retarded if the percentile was $<10$. 
The statistical analysis of the collected data was undertaken with the aid of the Windows $\mathbb{R}$ Statistical Package for the Social Sciences (SPSS), version 15.0. The comparison of motor development was made by group comparison tests. Student's ttest was used for the continuous variables. For the categorical variables the chi-squared $\left(\chi^{2}\right)$ or Fisher tests were used. A significance level of $5 \%$ was adopted for all the analyses.

\section{RESULTS}

Table 1 presents the descriptive results of the study group (SG) sample as regards the continuous biological and environmental variables.

Table 1: Descriptive results of the SG sample regarding the continuous biological and environmental variables ( $n=30$, for each age evaluated).

\begin{tabular}{|c|c|c|c|c|c|c|c|}
\hline Variable analysed (average) & Neonate & $\begin{array}{c}1 \\
\text { month }\end{array}$ & $\begin{array}{c}2 \\
\text { months }\end{array}$ & $\begin{array}{c}3 \\
\text { months }\end{array}$ & $\begin{array}{c}4 \\
\text { months }\end{array}$ & $\begin{array}{c}5 \\
\text { months }\end{array}$ & $\begin{array}{c}6 \\
\text { months }\end{array}$ \\
\hline Number of prenatal visits & 5.5 & 6.0 & 5.8 & 5.7 & 5.7 & 6.0 & 5.6 \\
\hline Total number of complications & 2.5 & 2.1 & 2.7 & 2.7 & 2.7 & 2.4 & 2.5 \\
\hline GA (per week) & 33.0 & 32.9 & 32.9 & 33.3 & 33.3 & 32.9 & 32.4 \\
\hline Birth weight (in grams) & 1611.0 & 1359.3 & 1504.8 & 1603.2 & 1602.2 & 1586.0 & 1528.8 \\
\hline Apgar score 1 & 6.1 & 7.0 & 6.6 & 6.5 & 6.5 & 6.0 & 6.2 \\
\hline Apgar score 5 & 7.7 & 8.6 & 8.4 & 8.2 & 8.2 & 7.8 & 7.9 \\
\hline Neonatal Medical Index & 2.7 & 2.5 & 2.9 & 2.7 & 2.7 & 2.7 & 2.8 \\
\hline Clinical Risk 1 & 0.8 & 0.8 & 1.3 & 0.7 & 0.7 & 0.9 & 0.6 \\
\hline Clinical Risk 2 & 2.1 & 1.8 & 2.6 & 1.9 & 1.9 & 1.9 & 2.4 \\
\hline Number of baby's complications & 3.8 & 4.2 & 4.4 & 3.7 & 3.7 & 3.6 & 4.1 \\
\hline Length of stay in hospital (in number of days) & 32.7 & 33.6 & 38.9 & 31.9 & 31.9 & 33.7 & 37.8 \\
\hline Number of children per mother & 1.7 & 1.4 & 1.6 & 1.6 & 1.6 & 1.6 & 1.9 \\
\hline Family income (minimum wages) & 2.8 & 2.8 & 3.1 & 3.3 & 3.3 & 2.8 & 2.8 \\
\hline Total score on the AIMS & 3.7 & 5.3 & 7.2 & 13.0 & 13.0 & 17.8 & 21.0 \\
\hline
\end{tabular}

NN (neonate); GA (gestational age); AIMS (Alberta Infant Motor Scale)

It may be observed that the average number of prenatal visits was above five for all ages. The mean gestational age was of 32.4 to 33.3 weeks. The average weight at all the ages evaluated classified infants as being of low birth weight (<2500 grams).

Through the analysis of the neonatal clinical risk indicators (Neonatal Medical Index, Clinical Risk 1 and 2), the infants were considered as presenting low neonatal clinical risk (mean $<3$ ). With regard to family income, most of the families belong to the low income bracket (the average of all the age groups is less than 3.5 Brazilian minimum wages).

Regarding the total score on AIMS, the score is seen to increase with age.

Table 2 gives the descriptive results of the control group sample (CG) as to continuous environmental and biological variables $(n=236)$.

Table 2: Descriptive results of the CG sample regarding the continuous biological and environmental variables $(n=236)$

\begin{tabular}{|c|c|c|c|c|c|c|c|}
\hline Variable analysed (average) & $\begin{array}{c}\text { Newborn } \\
(\mathrm{N}=28)\end{array}$ & $\begin{array}{c}1 \\
\text { month } \\
(n=36)\end{array}$ & $\begin{array}{c}2 \\
\text { months } \\
(n=36)\end{array}$ & $\begin{array}{c}3 \\
\text { months } \\
(n=34)\end{array}$ & $\begin{array}{c}\mathbf{4} \\
\text { months } \\
(n=35)\end{array}$ & $\begin{array}{c}5 \\
\text { months } \\
(n=33)\end{array}$ & $\begin{array}{c}6 \\
\text { months } \\
(n=34)\end{array}$ \\
\hline GA (in weeks) & 32.3 & 32.9 & 32.4 & 32.4 & 32.5 & 32.7 & 32.6 \\
\hline Birth weight (in grams) & 1664.6 & 1679.1 & 1616.4 & 1757.6 & 1642.4 & 1665.4 & 1569.4 \\
\hline Total score on the AIMS & 4.3 & 6.7 & 8.8 & 12.0 & 20.7 & 20.7 & 23.9 \\
\hline
\end{tabular}

NN (newborn); GA (gestational agel); AIMS (Alberta Infant Motor Scale)

The mean gestational age was of between 32.3 and 32.9 weeks. The mean birth weight was not greater than 1600 grams at the age of six months (1569.4 grams). Regarding the AIMS total score, there was also an increase in score with age.

As a complement to the results of the CG, the mean Apgar scores in the first and fifth minutes were eight and nine, respectively. And in relation to family income, the highest percentage of households (33\%) had a monthly income ranging from three to four times the Brazilian national minimum wage.

Whereas the overall goal of the study was to compare the motor development of preterm infants of two Brazilian regional samples after the objects of analysis had been described (i.e., the study and control groups), table 3 shows the comparative results of the two infant groups in relation to the total score on the AIMS as well as the classification according to that scale. 
Table 3: Comparison of groups as regards the total score on the AIMS and classification according to the AIMS percentile values

\begin{tabular}{|c|c|c|c|c|c|c|c|c|}
\hline \multirow[t]{2}{*}{ Age Evaluated } & \multirow{2}{*}{$\begin{array}{c}\text { Group } \\
\text { Evaluated }\end{array}$} & \multirow[t]{2}{*}{$\mathbf{n}$} & \multirow[t]{2}{*}{ Average } & \multirow{2}{*}{$\begin{array}{l}\text { Standard } \\
\text { Deviation }\end{array}$} & \multirow[t]{2}{*}{ P-Value } & \multicolumn{3}{|c|}{ Classification ( $\%)$} \\
\hline & & & & & & Normal & Suspicious & Delayed \\
\hline \multirow[t]{2}{*}{ Neonate } & SG & 30 & 3.7 & 1.9 & 0.851 & 23 & 60 & 17 \\
\hline & CG & 28 & 4.3 & 1.6 & & 39 & 46 & 14 \\
\hline \multirow[t]{2}{*}{1 month } & SG & 30 & 5.3 & 2.1 & 0.099 & 37 & 33 & 30 \\
\hline & CG & 36 & 6.7 & 1.7 & & 28 & 61 & 11 \\
\hline \multirow[t]{2}{*}{2 months* } & SG & 30 & 7.2 & 2.6 & 0.245 & 10 & 70 & $20 *$ \\
\hline & CG & 36 & 8.8 & 1.9 & & 22 & 72 & 6 \\
\hline \multirow[t]{2}{*}{3 months* } & SG & 30 & 9.3 & 2.8 & 0.413 & 17 & 43 & $40 *$ \\
\hline & CG & 34 & 12 & 2.7 & & 32 & $65^{*}$ & 3 \\
\hline \multirow[t]{2}{*}{4 months } & SG & 30 & 13 & 4 & 0.088 & 17 & 50 & 33 \\
\hline & CG & 35 & 14.9 & 3.2 & & 20 & 63 & 17 \\
\hline \multirow[t]{2}{*}{5 months } & SG & 30 & 17.8 & 5.8 & 0.163 & 20 & 47 & 33 \\
\hline & CG & 33 & 20.7 & 4.2 & & 27 & 49 & 24 \\
\hline \multirow[t]{2}{*}{6 months } & SG & 30 & 21 & 6.6 & 0.22 & 13 & 43 & 43 \\
\hline & CG & 34 & 23.9 & 4.5 & & 6 & 71 & 24 \\
\hline
\end{tabular}

SG (study group); CG (comparison group);

$* \mathrm{p}<0.05$ (statistically significant difference); T-Student test

There were no statistically significant differences in the total score of infants by the AIMS for any of the ages compared. The infants of both the SG and CG were thus considered similar as regards motor development, although some differences were noted as between the gestational age (SG> CG) and birth weight variables (CG > SG).

In the light of the result of the development classification proposed by the AIMS, the current study found that at two and three months of age the SG had a higher prevalence (20\% and $40 \%$, respectively) of delay among infants than did the CG $(6 \%$ and $3 \%)$. For the other age groups, the group classification was similar.

\section{DISCUSSION}

The first aspect to be observed relates to the samples selected. Two groups were formed as homogeneous as possible, so that both of them would be composed of preterm infants characterized by their risk conditions, such as low birth weight and moderate prematurity. The inclusion and exclusion criteria were the same for both groups in order to facilitate the comparison and assessment of the differences between them.

Regarding the comparison of groups by gestational age, at most of the key ages that were assessed, the infants were different, indicating that the infants of the study group were more mature than those of the CG, although the average gestational ages were very close.

It is known that gestational age is an important biological identifier for maturation of the fetus, which may influence its sensorimotor responses. However, the study ${ }^{24}$ compared the motor development of preterm infants (of corrected age) with those born full term, at eight and twelve months of age. The authors reported no significant difference in the control groups, but concluded that the way preterm infants and full term infants acquire their functional abilities occurs differently ${ }^{24}$.

In addition to gestational age, another factor that may negatively influence motor development is low birth weight. However, despite low weight's being considered a risk factor in the development of the infant, it should not be analyzed isolatedly ${ }^{25}$. In the current research, in all the ages tested, it was noted that the infants weighed less than 2500 grams. When comparing the birth weights of the groups, it was found that the CG was of slightly higher weight than the GE, in most age groups.

In the study ${ }^{26}$, a comparison was made between the cognitive and motor development of 152 infants born full term with low birth weight $(<2500 \mathrm{~g})$ and those of normal weight (3000 to $3499 \mathrm{~g})$, at two years of age. The authors obtained results that demonstrate the influence of low birth weight, within the $3 \%$ range, on the cognitive level, and $5 \%$ on the motor level. Cognitive development is associated with several development indicators, including the motor aspect ${ }^{27}$, and the motor development may be affected by low birth weight as well as by the long-term use of mechanical ventilation, low educational level of the mother and high rate of family conflict ${ }^{27}$. As in the current study, these data demonstrate that variables must be analyzed together, because the relationship between them can have a negative impact on infant motor development.

Although biological factors exercise a major influence on infant motor development, we cannot leave aside the discussion of environmental factors. The infants in this study are from two state capitals - Goiânia, GO (SG) and São Paulo, SP (CG) - which offer highly differing living conditions and lifestyles: We may say that they are subject to different environmental influences due to their contrasting economic and cultural characteristics. However, 
even with these differences, the current study did not observe any differences in motor development scores as between the two groups of infants.

The family environment also influences child growth and development, especially in early childhood. With regard to family income, the infants were all from low-income families, whose average family income, across all the age groups, was of less than 3.5 Brazilian legal minimum wages. It was found that low-income families are more likely to be subject to suspicion of delay than families of better financial condition ${ }^{28}$. Low parental level of education, closely related to their financial condition, also has a negative influence on the infants' motor development ${ }^{18}$.

Socioeconomic status also determines the number of prenatal visits made, which tends to be higher when the acquisitive power is better. Prenatal care is very important, seeing that the number of visits is inversely proportional to the risk factor of the infant and helps earlier to detect the risk of underweight birth. It can be seen that in both the groups, the average number of prenatal care visits made was greater than five at all ages.

Finally, a comparison between the groups was made as regards the total AIMS score, and no significant differences were found at any of the ages compared. It was ascertained in this study that the variables GA and birth weight were balanced between the groups of infants, because whereas one group had a greater GA (SG), the other had greater weight (CG). However, the study ${ }^{24}$ has detected that infants with lower gestational age had a lower percentile than full term infants, as assessed by the AIMS.

Although the groups were considered similar in relation to the total AIMS score at all the ages tested, at two and three months of age the infants of the two groups were classified differently as regards motor development, indicating that in the SG there was a higher frequency of delayed motor development.

As in our study, the motor development of a group of healthy and full term six-month-old Brazilian infants was compared to the reference standards of Canadian infants (AIMS). The results showed periods of transition in which the Brazilian infants showed a faster rate of motor acquisition and a peak in mean scores. Such changes show that the pace of motor development is not constant ${ }^{22}$.

AIMS was recently validated for the full-term and preterm infant populations of the State of Rio Grande do Sul ${ }^{29}$ and of Brazil as a whole ${ }^{30}$. The study ${ }^{30}$ revealed that, except for the neonates' age, infants of from six months to one year of age showed a more delayed motor development than did those of the Canadian standard. It is thus clear that the best way to study the motor development of a population of preterm infants is by comparing groups of the same degree of prematurity within the same cultural reality. This present study satisfies this condition, as it used samples taken from two different regions of Brazil.

In view of the variation seen in the results of the studies quoted ${ }^{3,30}$, it is evidently important to establish monitoring programs for infants at biological and environmental risk as per their region or city in order to prevent the emergence or worsening of sequelae in their development. The study $^{3}$ has, accordingly, found that the ratio for delays in gross motor development increases with age (14\% at 18 months, 33\% at three years and $81 \%$ at five years of age), especially in children whose birth weight was below $750 \mathrm{~g}^{3}$. Thus this study may be regarded as indicative of preventive measures for the health care of the infant at risk.

The results of this study could have gone into greater detail regarding the biological and environmental risk factors cited. However, no comparison has been made of the groups in relation to other criteria such as: number of prenatal visits, type of delivery, number of maternal and neonatal complications, number of children per mother, score on the AIMS in each bodily position (prone, supine, sitting and standing), parents' marital status, socioeconomic class of the families according to ABEP, as Restiffe's study ${ }^{23}$ has not provided such data.

The samples of infants studied were considered homogeneous with regard to most of their biological and social characteristics, given that the infants were from public hospitals that operate under Brazil's Unified Public Health System (SUS). However, in relation to GA and birth weight, differences were observed in some age groups.

Regarding the total score, no significant differences were found, and both groups were similar in terms of total AIMS score at all the ages assessed. But in the motor development classification, infants of the SG aged two and three months were considered delayed in the comparison with those of the CG.

These results suggest that preterm infants from different regions, although subject to different environmental influences, undergo similar motor development. Based on the study results, AIMS is shown to be a good tool for the assessment of infants. It is important to emphasize the need for further research in this field, with a view to creating closer control of the environment in which the infant is brought up, including the maternal and stimulation practices to which it is subject. 


\section{REFERENCES}

1. Figueiras AC, Souza ICN, Rios VG, Benguigui Y. Manual para Vigilância do Desenvolvimento Infantil no Contexto da AIDPI: Module II. Washington: OPAS, 2005

2. Nakahara AL, Martins AC, Cavalcanti FPB. Repercussões no desenvolvimento neuropsicomotor em recém-nascidos de risco. Rev. Fisio \& Terapia. 2002 Oct/Nov; (35): 10-12.

3. Goyen T, Lui K. Longitudinal motor development of "apparently normal" high-risk infants at 18 months, 3 and 5 years. Early Human Development. 2002; 70: 103-115.

4. Malinowski, C.; Wilson, B. Terapia respiratória neonatal e pediátrica. In: Scalan, G. L.; Wilkins, R. L.; Stoller, J. K. Fundamentos da Terapia Respiratória de Egan. São Paulo: Manole, 2000.

5. Carvalho AEV, Linhares MBM, Padovani FHP, Bordin MBM, Martins IMB, Martinez FEA. A compreensão do fator de risco da prematuridade sob a ótica desenvolvimental. In: Marturano EM, Linhares MBM, Loureiro SR. Vulnerabilidade e proteção: indicadores na trajetória de desenvolvimento escolar. São Paulo: Casa do Psicólogo, 2004. p. 11-38.

6. Gregório CSB, Pinheiro ECT, Campos DEO, Alfaro EJ. Evolução neuromotora de um recémnascido pré-termo e a correlação com os fatores perinatais. Rev. Fisiobrasil. 2004 May/ Jun; 65.

7. Formiga, CKMR. Detecção de Risco para Problemas no Desenvolvimento de Bebês Nascidos Pré-termo no Primeiro Ano [Thesis]. Ribeirão Preto: Universidade de São Paulo, 2009.

8. Ferreira, APA; Albuquerque, RC; Rabelo, ARM; Farias, FC; Correia, RCB; Gagliardo, HGRG; Lima, ACVMS. Comportamento visual e desenvolvimento motor de recém-nascidos prematuros no primeiro mês de vida. Rev. Bras. Crescimento Desenv. Hum. 2011; 21(2): 335-343.

9. Guimarães, CLN; Reinaux, CM; Botelho, ACG; Lima, GMS; Filho, JEC. Motor development evaluated by Test of Infant Motor Performance: comparison between preterm and full-term infants. Rev. bras. fisioter. 2011 Sep/Oct;15 (5): 357-362.

10. Maia, PC; Silva, LP; Oliveira, MMC; Cardoso, MVLML. Desenvolvimento motor de crianças prematuras e a termo - uso da Alberta Infant Motor Scale. Acta Paul. Enferm. 2011; 24 (5): 670-675.

11. Nicolau, CM; Costa, APBM.; Hazime, HO; Krebs; VLJ. Desempenho motor em recém-nascidos pré-termo de alto risco. Rev. Bras. Crescimento Desenv. Hum. 2011; 21 (2): 327-334.

12. Bordin MBM, Linhares MBM, Jorge SM. Aspectos cognitivos e comportamentais na média meninice de crianças nascidas pré-termo e com muito baixo peso. Psic.: Teor. e Pesq. 2001 jan/ abr; 17(1): 49-57.

13. Marcondes, E. Pediatria Básica. São Paulo: Sarvier, 2004.

14. Assunção, PL; Novaes, HMD; Alencar, GP; Melo, ASO; Almeida, MF. Desafios na definição da idade gestacional em estudos Populacionais sobre parto pré-termo: o caso de um estudo em Campina Grande (PB), Brasil. Rev. bras. epidemiol. 2011 ; 14 (3): 455-66.
15. Amorim RHC, Magalhães LC, Paixão ML, Barros CGC. Acompanhamento do Recém-nascido de Risco. In: Fonseca LF, Pianetti G, Xavier CC. Compêndio de Neurologia Infantil. Rio de Janeiro: Medsi, 2002.

16. Piek JP. The Influence of Preterm Birth on Early Motor Development. In: Motor Behavior and Human Skill: A Multidisciplinary Approach. United States of America: Human Kinetics, 1998. p. 233-51.

17. Magalhães LC, Catarina PW, Barbosa VM, Mancini MC, Paixão ML. Estudo comparativo sobre o desempenho perceptual e motor na idade escolar em crianças nascidas pré-termo e a termo. Arq Neuropsiquiatr. 2003; 61(2-A): 250-55.

18. Santa-Maria-Mengel MRS, Linhares MBM. Fatores de risco para problemas de desenvolvimento infantil. Rev. Latino-Am. Enfermagem. 2007 Set/Oct; (15).

19. Piper M, Darrah J. Motor assessment of the developing infant. EUA: W. B. Saunders Company, 1994.

20. Herrero, D; Gonçalves, H; Siqueira, AAF; Abreu, LC. Escalas de desenvolvimento motor em lactentes: Test of Infant Motor Performance e a Alberta Infant Motor Scale. Rev. Bras. Crescimento Desenv. Hum. 2011; 21 (1): 122-132.

21. Campos, D.; Santos, DCC.; Gonçalves, VMG.; Goto, MMF.; Arias, AV.; Brianeze, ACGS. ; Campos, TM.; Mello, BBA. Concordância entre escalas de triagem e diagnóstico do desenvolvimento motor no sexto mês de vida. J. Pediatr. 2006 Nov/Dec; 82(6).

22. Lopes VB. Desenvolvimento Motor Axial de Lactentes [dissertação]. São Paulo: Universidade Federal de São Carlos; 2003.

23. Restiffe AP. O desenvolvimento motor dos recém-nascidos pré-termo nos primeiros seis meses de idade corrigida segundo Alberta Infant Motor Scale: um estudo de coorte [term paper]. São Paulo: Faculdade de Medicina da Universidade de São Paulo, 2004.

24. Mancini MC, Teixeira S, Araújo LG, Paixão ML, Magalhães LC, Coelho ZAC. et al. Estudo do desenvolvimento da função motora aos 8 e 12 meses de idade em crianças pré-termo e a termo. Arq Neuropsyquiatr. 2002 Dec; 60(4).

25. Formiga CKMR, Pedrazzani ES. A Prevenção de Deficiências no Alvo da Educação Especial. Rev. bras. educ. espec. 2004 Jan/Apr; 10(1): 107-122.

26. Eickmann, SH; Lira, PIC; Lima, MC. Desenvolvimento mental e motor aos 24 meses de crianças nascidas a termo com baixo peso. Arq. Neuropsiquiatr. 2002; 60 (3-B): 748-754.

27. Vieira, MEB; Linhares, MBM. Desenvolvimento e qualidade de vida em crianças nascidas prétermo em idades pré-escolar e escolar. J. Pediatr. 2011; 87(4): 281-91.

28. Halpern, R; Giugliani, ERJ; Victora, CG; Barros, FC; Horta, BL. Fatores de risco para suspeita de atraso neuropsicomotor aos 12 meses de vida. J. Pediatr. 2000;76(6):421-428.

29. Valentini NC, Saccani R. Escala Motora Infantil de Alberta: validação para uma população gaúcha. Rev Paul Pediatr 2011; 29(2): 231-238.

30. Valentini NC, Saccani R. Brazilian validation of the Alberta Infant Motor Scale. Phys Ther. 2012; 92(3): 1-8. 